\title{
IMPACT OF COUNSELING ON PSYCHO-SOCIAL PROBLEMS OF YOUTH
}

\author{
NASREENBANU ${ }^{1} \&$ K. YASHODA ${ }^{2}$ \\ ${ }^{1}$ Principal Scientist, AICRP-HD (All India Coordinated Research Project-Human Development) PGRC, \\ PJTSAU (Professor Jayashankar Telangana State Agricultural University), Rajendranagar, Hyderabad, India \\ ${ }^{2} S R F, A I C R P-H D, P G R C, P J T S A U$, Hyderabad, India
}

\begin{abstract}
Present study was taken up to address the Psycho-social behavioral problems of youth, who discontinued studies. A total of 150 drop outsformed the sample for the present study. Checklists developed by the unit (AICRP-Child Development) were used to find out the Psycho-social behavioral problems of the youth. Standardized scales were used to find out the coping responses and the family environment, perceived by the youth. Based on the results, Counseling sessions (Individual \& Group) were conducted for the selected sample and separate sessions were conducted for the mothers too. The post test scores indicated a positive impact, reflecting the effectiveness of the Counseling programme KEYWORDS:AICRP-Child Development, increasing independence from adult controls, rapidly occurring physical and psychological changes, exploration of social issues \& concerns
\end{abstract}

Received: Jul 08 2017, Accepted: Jul 23 2017, Published: Jul 26 2017, Paper Id.: IJESRAUG201710

\section{INTRODUCTION \& BACKGROUND}

India is the second most populous country in the world, with 1,336,286,256 (1.3 billion) people (May 2016), nearly one fifth of the world's population. India has an unrivalled youth demographic: 65\% of its population is 35 or under, and half the country's population of 1.25 billion people is under 25 years of age.

Youth are defined as those aged between 15 to 29, in the national youth policy (2014)Thisage-group constitutes $27.5 \%$ of India's population. This age is characterized by increasing independence from adult controls, rapidly occurring physical and psychological changes, exploration of social issues and concerns, increased focus on activities with a peer group and establishment of a basic self identity (Hurlock, 1981).

It is a stressful developmental period filled with major changes in physical maturity and sexuality, cognitive process, emotional feelings and relationship with others. It is a phase of life marked by special attributes like rapid physical, psychological, cognitive and behavioral changes and developments,including urge to experiments, attainment of sexual maturity, development of adult identity,and transition from socio- economic dependence to relative independence.

Note: The Investigator is a trained Counselor by Hyderabad Psychological Association.

The consequent reduction of support and guidance can leave many youth to problematic behaviors, reducing their ability to respond in a healthy way when faced with struggling circumstances or difficult decisions (Haugaard, 2001). The majority of young people are confronted by more or less serious problems connected with their home life, their school experiences, their work activities and their social relationships. 
Increasing independence from adult controls, rapidly occurring physical and psychological changes, exploration of social issues and concerns, increased focus on activities with a peer group and establishment of a basic selfidentification, contribute to adolescent maladjustment. Factors for adolescent maladjustment include economic instability, parental discord, inadequacy of school offerings, and lack of understanding of adolescent psychology on the part of parents and school faculties, and inadequate recreational facilities.

The term psychosocial problems described as the maladaptive, unhealthy, intrapersonal, emotional and behavioral states (Gilbornetal, 2006). If people experience psychosocial problems, it may lead to maladaptive, unhealthy interpersonal networks, human relationships, social connections, and social malfunctioning. Study (Betancourt etal, 2009) conducted on psychosocial problems of adolescence were found to be associated with development of mental health disorders especially depression, anxiety, substance abuse, and psychosis also.

\section{OPERATIONAL DEFINITION}

Counseling is face-to-face communication through a dynamic process of interaction between two or more people during which the counselor helps the client to take decisions. It involves active listening to people talking about their problems; giving them comfort in an atmosphere of empathy and helping them to work out what to do about their problems, working at the empowerment of the client.

Counseling is a helping relationship aimed at enabling a client to explore a personal problem, giving the client increased awareness of choices than what they already have in dealing with the problem, and assisting her/him to make an informed decision what to do about the problem.

Risk Factors are individual or environmental characteristics, conditions, or behaviours that increase the likelihood that a negative outcome will occur.

\section{Psycho-Social Problems}

The term psychosocial refers to the psychological and social factors that influence mental health. Social influences such as peer pressure, parental support, cultural and religious background, socioeconomic status, and interpersonal relationships all help to shape personality and influence psychological makeup.

\section{METHODOLOGY}

Out of 1255 sample, from the selected villages (5) of Moinabadmandal150 youth (17 -25 years) who discontinued studies were selected for qualitative research study purpose.

\section{General Objective: Impact of Counselling on Psycho-Social Problems of Rural Youth Specific Objectives}

- To find out the Psycho-social problems of Rural youth

- To find out the Risk factors associated with Psycho-social problems of Rural youth

- To find out the Coping responses of the Rural youth

- To find out the Family environment as perceived by the Rural youth

- To conduct Counseling sessions for the Rural youth with Psycho-social problems 
- To study the impact of Intervention (Counselling sessions) on the Psycho-social problems of Rural youth

- To develop and to disseminate IEC material in vernacular language for the key persons in the village for the continuation of the programme:

\section{Research Strategy Adopted}

In order to achieve the framed objectives counseling sessions \& capacity building programmes, were planned to empower the youth.

\section{Research Tool}

Psycho-Social Behavioral Problem Checklist for youth (17-25 yrs): It is developed by AICRP-CD, Hyd Unit (2015). The scale is designed to measure four areas: Psychological problems; Emotional problems; Behavioral / Anti social behavior and Social / or relationship problems. Psychological problem area has 20 statements, Emotional problem area has 10 statements, Behavioral / Anti socialbehavior area has 13 statements and Social / or relationship problem area has 13 statements.

Altogether, Psycho-Social Problems checklist consists of 56statements, which are arranged on 5 point scale i.e.Most of the timeis marked as 5; Oftenis marked as 4; Some timesis marked as 3; Rarelyis marked as 2 and Not at all is marked as 1.The total scores were further grouped as Normal / no problem; Mild level of problem; Moderate level of problem; Severe level of problem and Extreme level of problem. Based on the level \& in which area youth has problem, intervention will be planned accordingly.

\section{Risk Factors Associated With Psycho- Social Problems Among Youth}

It is developed by AICRP-CD, Hyd Unit (2015).The scale is designed to measure three areas: Environmental Factors, Interpersonal and Social Factors and Individual Factors. Environmental Factors has 8 statements, Interpersonal and Social Factors has8 statements, and Individual Factors has8 statements.

Altogether, Psycho-Social Problems checklist consists of 24statements, which are arranged on 5 point scale i.e., Very true is marked as 5; Somewhat true is marked as 4; True is marked as 3; Not true is marked as 2 and Not at all true is marked as 1.The total scores were further grouped as No risk; Mild level of risk; Moderate level of risk; Severe level of risk and Extreme level of risk. Based on the level \& in which area the youth has problem, intervention will be planned accordingly.

\section{Coping Response Inventory}

For the present study Coping response inventory (Moos, 1993a) was used, which measures both approach and avoidance coping. It further divides these domains into categories that reflect cognitive or behavioral coping. Thus as shown in Table 3, the CRI organizes coping responses in to eight dimensions. The first four dimensions measure approach coping and the second four dimensions measure avoidance coping. The first two scales in each set measure cognitive coping strategies; the third and fourth scale each set measures behavioral coping strategies.

Table 1: Coping Responses Inventory Domains

\begin{tabular}{|c|l|l|}
\hline Type of Coping & \multicolumn{1}{|c|}{ Approach } & \multicolumn{1}{c|}{ Avoidance } \\
\hline \multirow{2}{*}{ Cognitive coping } & Logical analysis & Cognitive avoidance \\
\cline { 2 - 3 } & Positive reappraisal & Resigned acceptance \\
\hline
\end{tabular}




\begin{tabular}{|l|l|l|}
\hline \multirow{2}{*}{ Behavioral coping } & Seek guidance/support & Seeking alternative rewards \\
\cline { 2 - 3 } & Problem solving & Emotional discharge \\
\hline
\end{tabular}

Each of these 8 dimensions or scales is composed of 6 items. On responding to the CRI, individuals select and describe a recent stressor and it uses a 4 point scale varying from not at all to fairly often to rate their reliance on each of 48 coping items. It also includes as set of 10 items that provide information on how respondents appraise the stressor and its outcome. CRI can be administered as a self-report inventory or a structured interview. The test-reliability was found to be $(\mathrm{p}<.001)$.

\section{Family Environment Scale}

For the present study Family Environment Scale developed by Bhatia and Chadha (1996) was used.It is a modified version of Moos and Moos (1974) Family environment scale. Family environment is influenced by a number of factors like the nature of family constellation, number of children in the family; marital relationship between husband and wife; maternal employment, socio economic status; and religious back ground of the family.

The scale measures eight dimensions, which are grouped in three major dimensions. These are:

\section{Relationship Dimension}

- Cohesion:Degree of commitment, help and support family members provide for one another.

- Expressiveness:Extent to which members are encouraged to act openly and express their feelings and thoughts directly.

- Conflict:Amount of openly expressed aggression and conflict among family members.

- Acceptance and Caring: Extent to which the members are unconditionally accepted and the degree to which caring is expressed in the family.

- Personal growth Dimension:

- Independence: Extent to which family members are assertive and independently make their own decisions.

- Active Recreational Orientation.Extent of participation in social and recreational activities.

- System maintenance dimension

- Organization: Degree of importance of clear organizational structure in planning family activities and responsibilities.

- Control degree of limit setting within a family.

The scale consists of 69 items both positive and negative with Likert scale ranging from strongly agree to strongly disagree, the score for each item ranges from 5 to 1 for positive items and 1 to 5 for negative items. The split half reliability of the scale ranged from 0.48 to 0.92 for 8 different dimensions of the scale. The overall test reliability coefficient is reported as 0.95 indicating that the scale is highly reliable and is consistent in measuring the construct, the family environment. 


\section{RESEARCH RESULTS}

\section{Characterization of Youth on Selected Parameters}

- Family Environment as Perceived by the Youth: The scale measures3 dimensions i.e. Relationship, Personal growth \& System maintenance dimension. In all these dimensions youth obtained average to low scores which reflects the need for intervention.

- Coping Responses of the youth: The scale measuresApproach\&Avoidance coping. Each dimension includesCognitive skills and behavioral skills. Youth were using low to moderate levels of approach coping \& were using moderate to high level of avoidance coping skills in dealing with the problematic situations.

- Psycho-Social Behavioral Problems: The scale is designed to measure 4 areas:Psychological; Emotional; Behavioral and Social / or relationship problems. Over all, half of the (55\%) sample was found in normal category, $\mathbf{3 7 . 5 \%}$ were observed to be having mild level and $7.5 \%$ were having moderate level of problems.

- Risk Factors Associated with Psycho- Social BehavioralProblems: The scale is designed to measure three factors: Environmental; Interpersonal \&Social; and Individual factors associated with Psycho- Social behavioral Problems. Over all, half the sample (50\%) was not having any risk, where as $\mathbf{3 2 . 5 \%}$ (13) were found to be having mild level and $\mathbf{1 7 . 5 \%}$ (7) were having moderate level of risk associated with psycho social problems.

\section{Intervention}

- Based on the perception of the youth towards family environment; Coping strategies used; Psycho- socio emotional problems; and factors contributing to Psycho- Socio emotional problems, counseling sessions were conducted. Based on the type of problem, individual and Group counseling (6 per group) sessions were conducted. Three sessions per week were conducted.

- Capacity building programmes,(10) \&Counseling sessions (10) were also organized for the Rural mothers for sensitizing them towards issues concerning youth

Counseling is often an effective way of dealing with psychosocial and emotional problems of clients facing problems. Anyone (with training) can do it, as long as one has the right attitude and skills. Behavior is often an open expression of feelings. In order to change problematic behavior, counseling requires dealing with feelings. Counseling focuses on the client's feelings, thoughts, and ideas that are essential too. Helping clients with problems requires an effective approach.

For the present study, Psycho-Social approach was used while counseling the subjects. 'Psycho' denoting the psychological elements which refers to feelings, thoughts, attitudes, emotions and are normally understood as "internal" and linked to the mind; and 'Social' as the relation between the person and the "external" word, such as the interactions in the family, at work and in general in the socio-cultural environment.

The psychosocial approach is an intervention, which looks at the clients' problem in relation to his/her environment. The (Social) environment includes society, family, school, and peers. The Psycho- (logical) part is concerned with mental processes such as feelings, thoughts, behavior, and motives. The client's problem situation is then analyzed and understood from his/her psychological, social, and cultural perspective. The client's internal capacities and social and cultural resources influence solutions and change. 
Psychosocial Counseling is a planned intervention between the client and the counselor to assist the client to alter, improve, or resolve his/her present behavior, difficulty, or discomforts. It is a process of helping the client to discover the coping mechanisms that he/she found useful in the past, how they can be used or modified for the present situation, and how to develop new coping mechanisms.

Counseling is about strengthening the ability of the child to solve problems and make decisions and is different from giving advice.Counseling is a process by means of which the helper expresses care and concern towards the person with a problem, and facilitates that person's personal growth and brings about change through self-knowledge.

It is designed to help people to understand and clarify their views, and learn how to reach their self-determined goals through meaningful, well-informed choices, and through the resolution of emotional or interpersonal problems.

\section{Purpose / or Benefits of Counseling}

- Helps clients gain an insight into the origins and development of emotional difficulties, leading to an increased capacity to take rational control over their feelings and actions

- Helps in altering maladjusted behavior

- Assists clients to move in the direction of fulfilling their potential, or achieve an integration of conflicting elements within themselves.

- $\quad$ Provides clients with the skills, awareness and knowledge, which will enable them to confront social inadequacy.

- Helps in working through problems with a skilled manner

- Helps in learning new behaviors and/or responses which can helps the client to achieve theirgoals
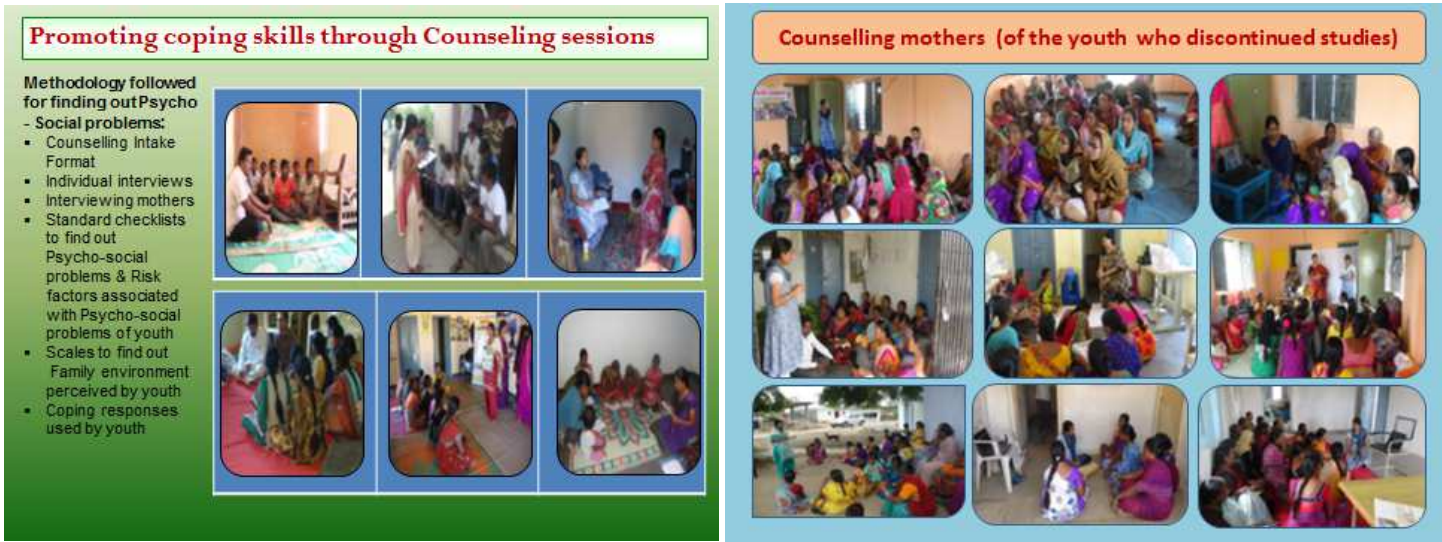


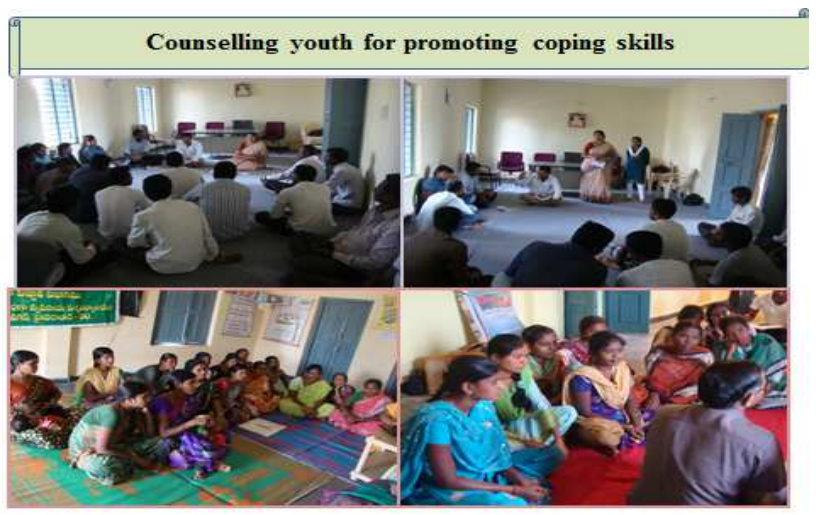

Figure 1

Table 1:Impact of Counselling on the Psycho-Social Behavioral Problems of Rural Youth (Who Discontinued Studies)

\begin{tabular}{|c|c|c|c|c|c|}
\hline \multirow{2}{*}{$\begin{array}{c}\text { Psycho-Social } \\
\text { Behavioral } \\
\text { Problem Area } \\
\end{array}$} & \multirow[b]{2}{*}{ Category } & \multirow[b]{2}{*}{ Score } & No \& \% & No \& \% & No \& \% \\
\hline & & & $\begin{array}{c}(\mathrm{N}=150) \\
\text { Pre }\end{array}$ & $\begin{array}{c}(\mathrm{N}=150) \\
\text { Post } 1\end{array}$ & $\begin{array}{c}\mathrm{N}=150) \\
\text { Post } 2\end{array}$ \\
\hline \multirow{3}{*}{$\begin{array}{l}\text { Psychological } \\
\text { problems (20) }\end{array}$} & Normal(1) & $<20$ & $83(55 \%)$ & $89(59 \%)$ & $96(64 \%)$ \\
\hline & Mild level of problem (2) & $20-40$ & $52(35 \%)$ & $48(32 \%)$ & $44(29 \%)$ \\
\hline & Moderate levelof problem (3) & $40-60$ & $15(10 \%)$ & $13(9 \%)$ & $10(7 \%)$ \\
\hline \multirow{3}{*}{$\begin{array}{l}\text { Emotional } \\
\text { problems (10) }\end{array}$} & Normal(1) & $<10$ & $78(52 \%)$ & $83(55 \%)$ & $93(62 \%)$ \\
\hline & Mild level of problem (2) & $10-20$ & $57(38 \%)$ & $54(36 \%)$ & $50(33 \%)$ \\
\hline & Moderate levelof problem (3) & $20-30$ & $15(10 \%)$ & $13(9 \%)$ & $7(5 \%)$ \\
\hline \multirow{2}{*}{$\begin{array}{l}\text { Behavioral } \\
\text { problems (13) }\end{array}$} & Normal(1) & $<13$ & $86(57 \%)$ & $96(64 \%)$ & $108(72 \%)$ \\
\hline & Mild level of problem (2) & $13-26$ & $64(43 \%)$ & $54(36 \%)$ & $42(28 \%)$ \\
\hline \multirow{3}{*}{$\begin{array}{l}\text { Social / or } \\
\text { relationship } \\
\text { problems (13) }\end{array}$} & Normal(1) & $<13$ & $83(55 \%)$ & $92(61 \%)$ & $102(68 \%)$ \\
\hline & Mild level of problem (2) & $13-26$ & $48(32 \%)$ & $43(29 \%)$ & $38(25 \%)$ \\
\hline & Moderate levelof problem (3) & $26-39$ & $19(13 \%)$ & $15(10 \%)$ & $10(7 \%)$ \\
\hline \multirow{3}{*}{$\begin{array}{l}\text { Over all } \\
\text { problem } \\
\text { intensity (56) }\end{array}$} & Normal(1) & $<56$ & $83(55 \%)$ & $93(62 \%)$ & $104(69 \%)$ \\
\hline & Mild level of problem (2) & $56-112$ & $55(37 \%)$ & $51(34 \%)$ & $42(28 \%)$ \\
\hline & Moderate levelof problem (3) & $112-168$ & $12(8 \%)$ & $6(4 \%)$ & $4(3 \%)$ \\
\hline
\end{tabular}

The scores in the above table clearly indicate the significant Impact of counselling on the Psycho-Social Problems ofyouth at different phases.

- With regard to Psychological problems, 83 subjects (55\%) who were in normal category, during pre-test, their number increasedto 89 (59\%) during post-test-I and to 96 (64\%) during post test-II in the same category.

- With regard to Emotional problems, 78 subjects (52\%) who were in normal category, during pre-test, their number increasedto $83(55 \%)$ during post test-I and to $93(62 \%)$ during post test-II in the same category.

- With regard to Behavioral problems, 86 subjects (57\%) who were in normal category, during pre-test, their number increasedto $96(64 \%)$ during post test-I and to 108 (72\%) during post test-II in the same category.

- With regard to Social / or relationship problems, 83 subjects (55\%) who were in normal category, during pretest, their number increased to $92(61 \%)$ during post test-I and to $102(68 \%)$ during post test-II in the same category.

- Overall, 83 subjects (55\%) who were in normal category with regard to Psycho-Social Behavioral Problems duringpre-test, their number increased to $62 \%$ (93) during post test-I and to $69 \%$ (104) during post test-II in the 
same category, which reflects the effectiveness of the counseling programme.

Table 2

\begin{tabular}{|l|c|c|c|c|c|c|}
\hline \multirow{2}{*}{ Area } & \multicolumn{3}{|c|}{ Total scores } & \multicolumn{3}{c|}{ Means } \\
\cline { 2 - 7 } & $\begin{array}{c}\text { Pre } \\
\text { test(A) }\end{array}$ & $\begin{array}{c}\text { Post } \\
\text { test- } \\
\mathbf{1}(\mathbf{B})\end{array}$ & $\begin{array}{c}\text { Post } \\
\text { test- } \\
\mathbf{2}(\mathbf{C})\end{array}$ & Pre test (A) & Post test-1(B) & $\begin{array}{c}\text { Post test- } \\
\text { 2(C) }\end{array}$ \\
\hline Psychol & 4005 & 3824 & 3817 & 26.7 & 25.49 & 25.45 \\
\hline Emotional & 2060 & 1954 & 1877 & 13.73 & 13.03 & 12.51 \\
\hline Behrl & 2582 & 2427 & 2322 & 17.21 & 16.18 & 15.48 \\
\hline Social & 2747 & 2572 & 2461 & 24.43 & 22.73 & 21.79 \\
\hline Total & 11394 & 10777 & 10477 & 82.07 & 77.43 & 75.23 \\
\hline
\end{tabular}

Table 3

\begin{tabular}{|l|c|c|c|c|c|}
\hline \multirow{2}{*}{ Area } & \multicolumn{3}{|c|}{ Mean Differences } & \multicolumn{2}{c|}{ T Values } \\
\cline { 2 - 6 } & A-B & A-C & B-C & A-B & A-C \\
\hline Psychol & 1.21 & 1.25 & 0.04 & $4.46^{* *}$ & $3.84 * *$ \\
\hline Emotional & 0.7 & 1.22 & 0.52 & $1.14 * *$ & $8.68 * *$ \\
\hline Behrl & 1.03 & 1.73 & 0.7 & $2.34 * *$ & $3.40^{* *}$ \\
\hline Social & 1.7 & 2.64 & 0.94 & $4.33^{* *}$ & $3.70^{* *}$ \\
\hline Total & $\mathbf{4 . 6 4}$ & $\mathbf{6 . 8 4}$ & $\mathbf{2 . 2}$ & $2.28^{* *}$ & $9.59 * *$ \\
\hline
\end{tabular}

Note: ** At 1\% Level of Significance

The above table presents theoverallPsycho-Social BehavioralProblemscores of youth,total raw scores, means, SD\& ' $T$ ' values at different phases (pre test and post test I \& II). The table shows the progressive increase in the total scores across pre test to post test $1 \& 2$, along with the increase in the mean differences, which shows the impact of intervention (Counseling) programme. T values between the two means of pre-test and post-test I \&II were found to be highly significant, as the calculated values were found to be greater than the tabulated value.

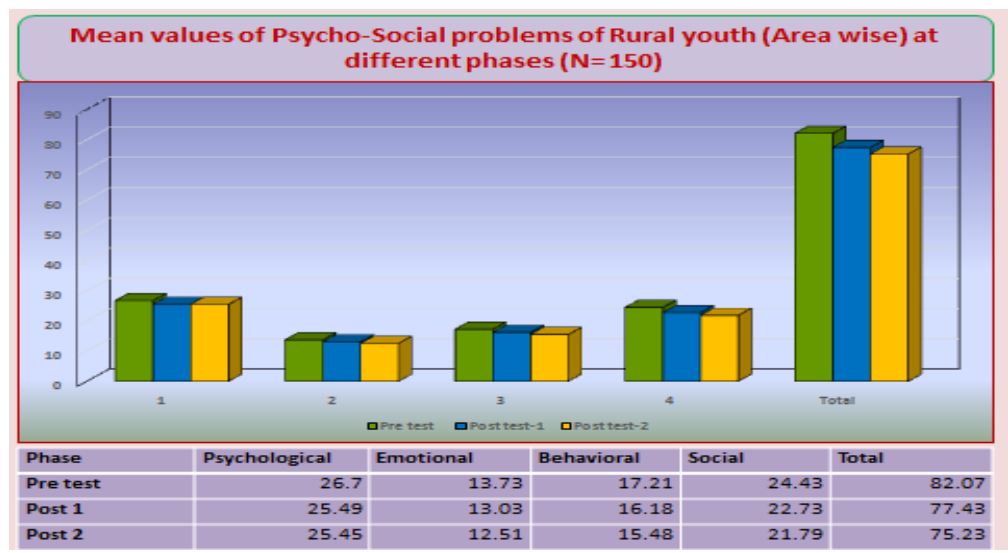

Figure 1: Mean Values of Psycho-Social Behavioral Problems of youth (Area Wise) N= 150

Table 4: Impact of Counselling on the Risk Factors Associated with Psycho-Social Behavioral Problems of Rural Youth (Who Discontinued Studies) N= 150

\begin{tabular}{|l|l|c|c|c|c|}
\hline \multirow{2}{*}{ Risk Factors } & \multicolumn{1}{|c|}{ Category } & Score & $\begin{array}{c}(\mathbf{N}=\mathbf{1 5 0}) \\
\text { Pre }\end{array}$ & $\begin{array}{c}\text { (N= 150) } \\
\text { Post 1 }\end{array}$ & $\begin{array}{c}\text { (N= 150) } \\
\text { Post 2 }\end{array}$ \\
\hline \multirow{2}{*}{$\begin{array}{l}\text { Environmental } \\
\text { Factors }(8)\end{array}$} & No risk (1) & $<8$ & $75(50 \%)$ & $81(54 \%)$ & $93(62 \%)$ \\
\cline { 2 - 6 } & Mild level of Risk (2) & $8-16$ & $42(28 \%)$ & $38(25 \%)$ & $30(20 \%)$ \\
\cline { 2 - 6 } & Moderate levelof Risk(3) & $16-24$ & $33(22 \%)$ & $31(21 \%)$ & $27(18 \%)$ \\
\hline Interpersonal \& & No risk (1) & $<8$ & $80(53 \%)$ & $90(60 \%)$ & $102(68 \%)$ \\
\hline
\end{tabular}




\begin{tabular}{|c|c|c|c|c|c|}
\hline \multirow[t]{2}{*}{ Social Factors (8) } & Mild level of Risk (2) & $8-16$ & $55(37 \%)$ & $48(32 \%)$ & $37(25 \%)$ \\
\hline & Moderate levelof Risk(3) & $16-24$ & $15(10 \%)$ & $12(8 \%)$ & $11(7 \%)$ \\
\hline \multirow{3}{*}{$\begin{array}{l}\text { Individual } \\
\text { Factors }(8)\end{array}$} & No risk (1) & $<8$ & $75(50 \%)$ & $87(58 \%)$ & $108(72 \%)$ \\
\hline & Mild level of Risk (2) & $8-16$ & $48(32 \%)$ & $41(27 \%)$ & $30(20 \%)$ \\
\hline & Moderate levelof Risk(3) & $16-24$ & $27(18 \%)$ & $22(15 \%)$ & $12(8 \%)$ \\
\hline \multirow{3}{*}{$\begin{array}{l}\text { Over all } \\
\text { intensity of the } \\
\text { risk factors (24) }\end{array}$} & No risk (1) & $<24$ & $75(50 \%)$ & $93(62 \%)$ & $111(74 \%)$ \\
\hline & Mild level of Risk (2) & $24-48$ & $48(32 \%)$ & $36(24 \%)$ & $27(18 \%)$ \\
\hline & Moderate levelof Risk(3) & $48-72$ & $27(18 \%)$ & $21(14 \%)$ & $12(8 \%)$ \\
\hline
\end{tabular}

The above table presents theImpact of counselling on the Risk factors associated with Resilience levels of rural youth at different phases.

- With regard to Environmental Risk Factors, 75 subjects (50\%)who were in normal category, during pre-test, their number increasedto $81(64 \%)$ during post test-I and to $93(62 \%)$ during post test-II in the same category, due to the effectiveness of counseling.

- With regard to Interpersonal \& Social Factors, 80subjects (75\%)who were in normal category, during pre-test, their number increased to $90(60 \%)$ during post test-I and to $102(68 \%)$ during post test-II in the same category, due to the effectiveness of counseling.

- With regard to Individual Factors,75 subjects (50\%)who were in normal category, during pre-test, their number increasedto $87(58 \%)$ during post test-I and to 108 (72\%) during post test-II in the same category, due to the effectiveness of counseling.

- Overall 86 subjects $(57 \%)$ who were in normal category, during pre-test, their number increased to 96 (64\%) during post test-I and to $108(72 \%)$ during post test-II in the same category, reflecting theeffectiveness of counseling.

Table 5: Risk Factors Associated with Psycho-Social Behavioral Problem Checklist for Youth (N=150)

\begin{tabular}{|l|c|c|c|c|c|c|}
\hline \multirow{2}{*}{ Area } & \multicolumn{3}{|c|}{ Total Scores } & \multicolumn{3}{c|}{ Means } \\
\cline { 2 - 7 } & Pre Test (A) & $\begin{array}{c}\text { Post Test-1 } \\
(\mathbf{B})\end{array}$ & $\begin{array}{c}\text { Post Test-2 } \\
(\mathbf{C})\end{array}$ & $\begin{array}{c}\text { Pre Test } \\
(\mathbf{A})\end{array}$ & $\begin{array}{c}\text { Post Test-1 } \\
(\text { B) }\end{array}$ & $\begin{array}{c}\text { Post Test-2 } \\
(\mathbf{C})\end{array}$ \\
\hline Environmental & 1700 & 1628 & 1592 & 11.33 & 10.85 & 10.61 \\
\hline $\begin{array}{l}\text { Interpersonal \& Social } \\
\text { Factors }\end{array}$ & 1570 & 1497 & 1478 & 10.47 & 9.98 & 9.85 \\
\hline Individual & 1731 & 1626 & 1482 & 11.54 & 10.84 & 9.88 \\
\hline \multicolumn{1}{|c|}{ Total } & $\mathbf{5 0 0 1}$ & $\mathbf{4 7 5 1}$ & $\mathbf{4 5 5 2}$ & $\mathbf{3 3 . 3 4}$ & $\mathbf{3 1 . 6 7}$ & $\mathbf{3 0 . 3 5}$ \\
\hline
\end{tabular}

Table 6

\begin{tabular}{|l|c|c|c|c|c|}
\hline \multirow{2}{*}{ Area } & \multicolumn{3}{c|}{ Mean Differences } & \multicolumn{2}{c|}{ T Values } \\
\cline { 2 - 7 } & A-B & A-C & B-C & A-B & A-C \\
\hline Environmental & 58 & 194 & 323323 & $\mathbf{1 . 2 2} * *$ & $\mathbf{1 . 6 3} * *$ \\
\hline $\begin{array}{l}\text { Interpersonal \& Social } \\
\text { Factors }\end{array}$ & 27 & 153 & 255 & $\mathbf{2 . 8 2} * *$ & $\mathbf{6 . 0 2} * *$ \\
\hline Individual & 26 & 59 & 84 & $\mathbf{5 . 3 8} * *$ & $\mathbf{2 . 9 3} * *$ \\
\hline \multicolumn{1}{|c|}{ Total } & $\mathbf{2 3}$ & $\mathbf{5 3}$ & $\mathbf{8 8}$ & $\mathbf{1 . 2 2} * *$ & $\mathbf{2 . 2 0} * *$ \\
\hline
\end{tabular}

Note: ** At 1\% Level of Significance

The above table presents the overall Risk Factors associated with Psycho-Social Behavioral Problem scores of youth,total raw scores, means, SD\& 'T' values at different phases (pre test and post test I \& II). The table shows the progressive increase in the total scores across pre test to post test $1 \& 2$, along with the increase in the mean differences, which shows the impact of intervention (Counseling) programme. T values between the two means of pre test and post test 
I \& II were found to be highly significant, as the calculated values were found to be greater than the tabulated value.

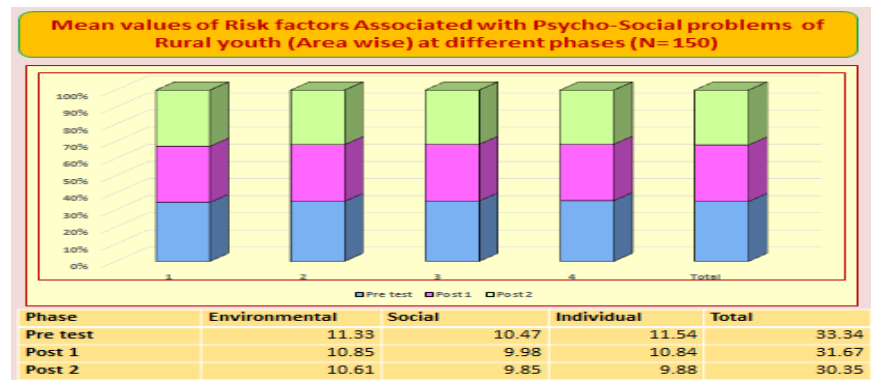

Figure 2: Mean values of Risk Factors associated with Psycho-Social Behavioral Problems of youth (Area wise)

Table 7: Impact of Counselingon the Family Environment as Perceived by the Rural Youth (who discontinued studies) $N=150$

\begin{tabular}{|c|c|c|c|c|c|}
\hline Family Environment & Category & Score & $\begin{array}{l}\text { No \& \% } \\
(\mathrm{N}=150)\end{array}$ & $\begin{array}{l}\text { No \& \% } \\
(\mathrm{N}=150)\end{array}$ & $\begin{array}{l}\text { No \& \% } \\
(\mathrm{N}=150)\end{array}$ \\
\hline \multicolumn{3}{|c|}{ I. Relationship Dimension } & Pre & Post 1 & Post 2 \\
\hline \multirow{3}{*}{ 1. Cohesion } & Low & $<45$ & $45(30 \%)$ & $37(25 \%)$ & $33(22 \%)$ \\
\hline & Average & $45-60$ & $68(45 \%)$ & $72(48 \%)$ & $57(38 \%)$ \\
\hline & High & $>60$ & $37(25 \%)$ & $41(27 \%)$ & $60(40 \%)$ \\
\hline \multirow{3}{*}{ 2. Expressiveness } & Low & $<27$ & $68(45 \%)$ & $53(35 \%)$ & $45(30 \%)$ \\
\hline & Average & $27-39$ & $63(42 \%)$ & $48(32 \%)$ & $48(32 \%)$ \\
\hline & High & $>39$ & $19(13 \%)$ & $49(33 \%)$ & $57(38 \%)$ \\
\hline \multirow{3}{*}{ 3. Conflict* } & $\begin{array}{l}\text { Low } \\
\text { conflict) }\end{array}$ & $<37$ & $33(22 \%)$ & $30(20 \%)$ & $27(18 \%)$ \\
\hline & Average & $37-51$ & $68(45 \%)$ & $63(42 \%)$ & $60(40 \%)$ \\
\hline & $\begin{array}{l}\text { High } \\
\text { conflict) }\end{array} \quad$ (low & $>51$ & $49(33 \%)$ & $57(38 \%)$ & $63(42 \%)$ \\
\hline \multirow{3}{*}{$\begin{array}{l}\text { 4. Acceptance \& } \\
\text { caring }\end{array}$} & Low & $<40$ & $23(15 \%)$ & $35(23 \%)$ & $30(20 \%)$ \\
\hline & Average & $40-54$ & $82(55 \%)$ & $68(45 \%)$ & $60(40 \%)$ \\
\hline & High & $>54$ & $45(30 \%)$ & $48(32 \%)$ & $60(40 \%)$ \\
\hline \multirow{3}{*}{ Total } & Low & $<76$ & $45(30 \%)$ & $37(25 \%)$ & $33(22 \%)$ \\
\hline & Average & $77-152$ & $68(45 \%)$ & $72(48 \%)$ & $57(38 \%)$ \\
\hline & High & $153-230$ & $37(25 \%)$ & $41(27 \%)$ & $60(40 \%)$ \\
\hline \multicolumn{6}{|c|}{ II. Personal Growth Dimension } \\
\hline \multirow{3}{*}{ 5. Independence } & Low & $<30$ & $37(25 \%)$ & $33(22 \%)$ & $30(20 \%)$ \\
\hline & Average & $30-40$ & $68(45 \%)$ & $57(38 \%)$ & $49(33 \%)$ \\
\hline & High & $>40$ & $45(30 \%)$ & $60(40 \%)$ & $71(47 \%)$ \\
\hline \multirow{3}{*}{$\begin{array}{l}\text { 6. Active - recreation } \\
\text { orientation }\end{array}$} & Low & $<25$ & $53(35 \%)$ & $45(30 \%)$ & $41(27 \%)$ \\
\hline & Average & $25-33$ & $63(42 \%)$ & $48(32 \%)$ & $45(30 \%)$ \\
\hline & High & $>33$ & $34(23 \%)$ & $57(38 \%)$ & $64(43 \%)$ \\
\hline \multirow{3}{*}{ Total } & Low & $<28$ & $37(25 \%)$ & $33(22 \%)$ & $30(20 \%)$ \\
\hline & Average & $29-56$ & $68(45 \%)$ & $57(38 \%)$ & $49(33 \%)$ \\
\hline & High & $57-85$ & $45(30 \%)$ & $60(40 \%)$ & $71(47 \%)$ \\
\hline \multicolumn{6}{|c|}{ III. System Maintenance Dimension } \\
\hline \multirow{3}{*}{ 7. Organization } & Low & $<6$ & $37(25 \%)$ & $30(20 \%)$ & $27(18 \%)$ \\
\hline & Average & $6-9$ & $68(45 \%)$ & $56(37 \%)$ & $49(33 \%)$ \\
\hline & High & $>9$ & $45(30 \%)$ & $64(43 \%)$ & $74(49 \%)$ \\
\hline \multirow{3}{*}{ 8. Control } & Low & $<13$ & $27(18 \%)$ & $37(25 \%)$ & $60(40 \%)$ \\
\hline & Average & $13-17$ & $60(40 \%)$ & $56(37 \%)$ & $50(33 \%)$ \\
\hline & High & $>17$ & $63(42 \%)$ & $57(38 \%)$ & $40(27 \%)$ \\
\hline
\end{tabular}




\begin{tabular}{|c|c|c|c|c|c|}
\hline \multirow{3}{*}{ Total } & Low & $<\mathbf{1 0}$ & $\mathbf{3 7}(\mathbf{2 5} \%)$ & $\mathbf{3 0}(\mathbf{2 0 \%})$ & $\mathbf{2 7}(\mathbf{1 8 \%})$ \\
\cline { 2 - 6 } & Average & $11-\mathbf{2 0}$ & $\mathbf{6 8}(\mathbf{4 5 \%})$ & $\mathbf{5 6}(37 \%)$ & $\mathbf{4 9}(33 \%)$ \\
\cline { 2 - 6 } & High & $\mathbf{2 1 - 3 0}$ & $\mathbf{4 5}(\mathbf{3 0 \%})$ & $\mathbf{6 4 ( 4 3 \% )}$ & $\mathbf{7 4}(\mathbf{4 9 \%})$ \\
\hline
\end{tabular}

The above table presents the Impact of counseling on the Family Environment Dimensions as perceived by the rural youth at different phases.

- 37 subjects (25\%) who obtained High scores in Relationship dimension under Family environment during pre test, their scores increasedto $27 \%$ (41) during post test-I and to $40 \%$ (60) during post test-II in the same category. Similar finding were observed with subjects who obtained low and average scores during pretest.

- The results indicate that the degree of commitment, help and support family members provided for one another was good; the family members were encouraged to act openly and express their feelings and thoughts directly and the family members were unconditionally accepted and cared by the family.

- This means the perception of youth towards relationship dimension changed for the better during post test scores, reflecting the effectiveness of counseling.

- 45 subjects (30\%) who obtained High scores in Personal growth dimension under Family environment during pre test, their scores increasedto $40 \%$ (60) during post test-I and to $47 \%$ (71) during post test-II in the same category. Similar finding were observed with subjects who obtained low and average scores during pretest.

- The results showed that the family members were allowed to be assertive and make their own decisionsindependentlyand the family members were allowed to participate in social and recreational activities.

This means the perception of youth towards personal growth dimension changed for the better during post test scores, reflecting the effectiveness of counseling (youth \& mothers).

45 subjects (30\%) who obtained High scores in System maintenance dimension under Family environment during pre test, their scores increasedto $43 \%$ (64) during post test-I and to $49 \%$ (74) during post test-II in the same category. Similar finding were observed with subjects who obtained low and average scores during pretest.

It shows that the family members were given importance in planning family activities and taking up responsibilities and a degree of limit was set on the family members within the family structure.

This means the perception of youth towards system maintenance dimension changed for the better during post test scores, reflecting the effectiveness of counseling.

Table 8

\begin{tabular}{|l|c|c|c|c|c|c|}
\hline \multirow{2}{*}{ Area } & \multicolumn{7}{c|}{ Total Scores } & \multicolumn{2}{c|}{ Means } & Post Test- \\
\cline { 2 - 7 } & Pre Test(A) & $\begin{array}{c}\text { Post Test- } \\
\mathbf{2}(\mathbf{C})\end{array}$ & $\begin{array}{c}\text { Pre test } \\
(\mathbf{A})\end{array}$ & $\begin{array}{c}\text { Post Test- } \\
\mathbf{1}(\mathbf{B})\end{array}$ & $\begin{array}{c}\text { Post Test- } \\
\mathbf{2}(\mathbf{C})\end{array}$ \\
\hline \multicolumn{7}{|c|}{ I. Relationship Dimension } \\
\hline Cohesion & 7331 & 7457 & 7544 & 48.87 & 49.71 & 50.29 \\
\hline Expressiveness & 4570 & 4785 & 4864 & 30.47 & 31.9 & 32.43 \\
\hline Conflict* & 6948 & 7142 & 7219 & 46.32 & 47.61 & 48.12 \\
\hline Acceptance \& caring & 6224 & 6414 & 6445 & 41.49 & 42.76 & 42.97 \\
\hline Total & 25073 & 25798 & 26072 & 167.15 & 171.99 & 173.81 \\
\hline \multicolumn{7}{|c|}{ IIIPersonal Growth Dimension } \\
\hline Independence & 4792 & 4978 & 5050 & 31.95 & 33.19 & 33.67 \\
\hline
\end{tabular}




\begin{tabular}{|l|c|c|c|c|c|c|}
\hline $\begin{array}{l}\text { Active - recreation } \\
\text { orientation }\end{array}$ & 4027 & 4181 & 4252 & 26.85 & 27.87 & 28.35 \\
\hline Total & 8819 & 9159 & 9302 & 58.79 & 61.06 & 62.01 \\
\hline \multicolumn{7}{|c|}{ III System Maintenance Dimension } \\
\hline Organization & 1092 & 1146 & 1188 & 7.28 & 7.64 & 7.92 \\
\hline Control & 2426 & 2305 & 2146 & 16.17 & 15.37 & 14.31 \\
\hline Total & 3518 & 3451 & 3334 & 23.45 & 23 & 22.23 \\
\hline
\end{tabular}

Table 9

\begin{tabular}{|l|c|c|c|c|c|}
\hline \multirow{2}{*}{ Area } & \multicolumn{3}{c|}{ Mean Differences } & \multicolumn{2}{c|}{ T Values } \\
\cline { 2 - 6 } & A-B & A-C & B-C & A-B & A-C \\
\hline Cohesion & 0.84 & 1.42 & 0.58 & $3.16^{* *}$ & $4.05^{* *}$ \\
\hline Expres & 1.43 & 1.96 & 0.53 & $1.33^{* *}$ & $6.05^{* *}$ \\
\hline Accept & 1.29 & 1.8 & 0.51 & $2.46^{* *}$ & $7.54^{* *}$ \\
\hline Conflictl* & 1.27 & 1.48 & 0.21 & $4.0^{* *}$ & $5.16^{* *}$ \\
\hline \multicolumn{5}{|c|}{ Table 9: Contd., } \\
\hline \multicolumn{7}{|c|}{ Total } & 4.84 & 6.66 & 1.82 & $1.54^{* *}$ & $2.03^{* *}$ \\
\hline Indep & 1.24 & 1.72 & 0.48 & $2.33^{* *}$ & $6.27^{* *}$ \\
\hline Recretn & 1.02 & 1.5 & 0.48 & $4.12^{* *}$ & $9.97^{* *}$ \\
\hline \multicolumn{1}{|c|}{ Total } & $\mathbf{2 . 2 7}$ & $\mathbf{3 . 2 2}$ & $\mathbf{0 . 9 5}$ & $\mathbf{5 . 8 2} * *$ & $\mathbf{4 . 9 5 * *}$ \\
\hline Orgnztn & 0.36 & 0.64 & 0.28 & $4.81^{* *}$ & $1.18^{* *}$ \\
\hline control & 0.8 & 1.86 & 1.06 & $1.75^{* *}$ & $4.35^{* *}$ \\
\hline \multicolumn{1}{|c|}{ Total } & $\mathbf{0 . 4 5}$ & $\mathbf{1 . 2 2}$ & $\mathbf{0 . 7 7}$ & $0.02^{* *}$ & $6.83^{* *}$ \\
\hline
\end{tabular}

The above table presents the overall Family environment (as perceived by youth) scores of youth total raw scores, means, and SD\& 'T' values at different phases (pre test and post test I \& II). The table shows the progressive increase in the total scores across pre test to post test $1 \& 2$, along with the increase in the mean differences, which shows the impact of intervention programme. T values between the two means of pre test and post test I \&II were found to be highly significant, as the calculated values were found to be greater than the tabulated value.

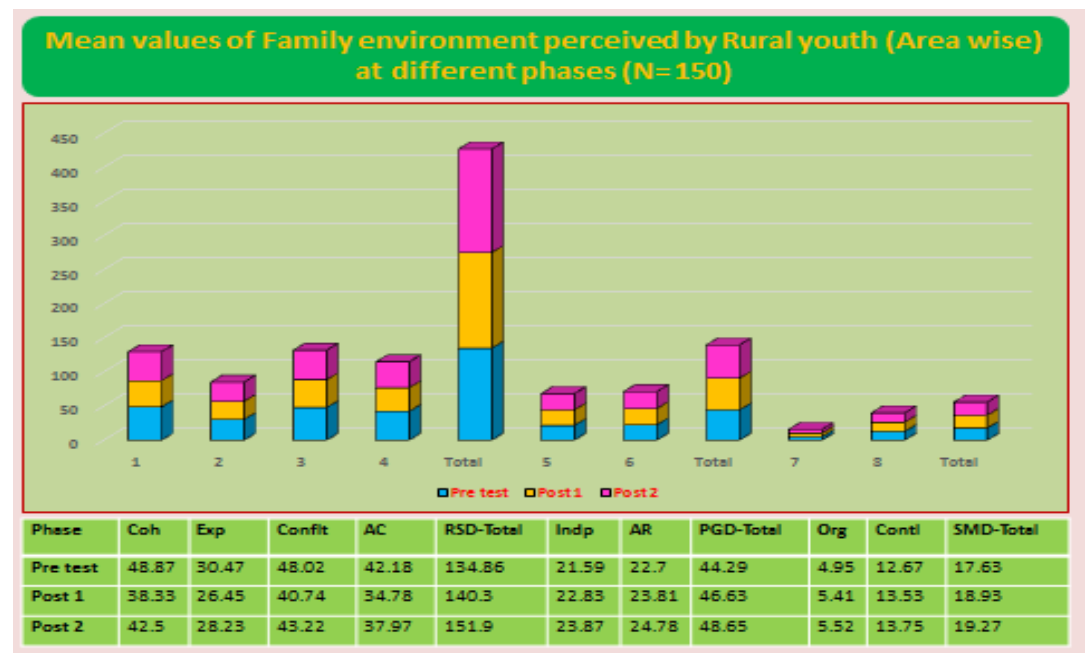

Figure 3: Mean Values of Family Environment as Perceived by the Youth (Area wise) N=150

Table 10: Impact of Counselingon the Coping Responses Used by the Rural Youth (who Discontinued Studies) $(\mathrm{N}=150)$

\begin{tabular}{|c|c|c|c|c|c|}
\hline Coping Response Approach & Category & Score & $\begin{array}{c}\text { No \& \% } \\
\text { Pre }\end{array}$ & Post 1 & Post 2 \\
\hline \multicolumn{2}{|c|}{ A. Approach Coping } & & $(\mathbf{N}=150)$ & $(\mathbf{N}=150)$ & $(\mathbf{N}=150)$ \\
\hline
\end{tabular}




\begin{tabular}{|c|c|c|c|c|c|}
\hline \multirow{3}{*}{ 1. Logical Analysis } & Low & $<8$ & $75(50 \%)$ & $48(32 \%)$ & $37(25 \%)$ \\
\hline & Average & $9-16$ & $48(32 \%)$ & $63(42 \%)$ & $51(34 \%)$ \\
\hline & High & $17-24$ & $27(18 \%)$ & $39(26 \%)$ & $62(41 \%)$ \\
\hline \multirow{3}{*}{ 2. Positive appraisal } & Low & $<8$ & $48(32 \%)$ & $39(26 \%)$ & $33(22 \%)$ \\
\hline & Average & $9-16$ & $68(45 \%)$ & $52(35 \%)$ & $48(32 \%)$ \\
\hline & High & $17-24$ & $34(23 \%)$ & $59(39 \%)$ & $69(46 \%)$ \\
\hline \multirow{3}{*}{ 3. Seek guidance \&support } & Low & $<8$ & $45(30 \%)$ & $39(26 \%)$ & $33(22 \%)$ \\
\hline & Average & $9-16$ & $68(45 \%)$ & $54(36 \%)$ & $48(32 \%)$ \\
\hline & High & $17-24$ & $37(25 \%)$ & $57(38 \%)$ & $69(46 \%)$ \\
\hline \multirow{3}{*}{ 4. Problem solving } & Low & $<8$ & $83(55 \%)$ & $45(30 \%)$ & $41(27 \%)$ \\
\hline & Average & $9-16$ & $48(32 \%)$ & $48(32 \%)$ & $45(30 \%)$ \\
\hline & High & $17-24$ & $19(13 \%)$ & $57(38 \%)$ & $64(43 \%)$ \\
\hline \multirow{3}{*}{ Total } & Low & $<32$ & $48(32 \%)$ & $39(26 \%)$ & $33(22 \%)$ \\
\hline & Average & $33-64$ & $68(45 \%)$ & $52(35 \%)$ & $48(32 \%)$ \\
\hline & High & $65-96$ & $34(23 \%)$ & $59(39 \%)$ & $69(46 \%)$ \\
\hline \multicolumn{6}{|c|}{ B. Avoidance Coping } \\
\hline \multicolumn{6}{|c|}{ Table 10: Contd., } \\
\hline \multirow{3}{*}{ 1. Cognitive avoidance } & Low & $<8$ & $12(8 \%)$ & $55(37 \%)$ & $63(42 \%)$ \\
\hline & Average & $9-16$ & $98(65 \%)$ & $52(35 \%)$ & $51(34 \%)$ \\
\hline & High & $17-24$ & $40(27 \%)$ & $42(28 \%)$ & $36(24 \%)$ \\
\hline \multirow{3}{*}{ 2. Acceptance } & Low & $<8$ & $23(15 \%)$ & $52(35 \%)$ & $60(40 \%)$ \\
\hline & Average & $9-16$ & $90(60 \%)$ & $59(39 \%)$ & $51(34 \%)$ \\
\hline & High & $17-24$ & $37(25 \%)$ & $39(26 \%)$ & $39(26 \%)$ \\
\hline \multirow{3}{*}{ 3. Seek alternative rewards } & Low & $<8$ & $37(25 \%)$ & $55(37 \%)$ & $65(43 \%)$ \\
\hline & Average & $9-16$ & $45(30 \%)$ & $53(35 \%)$ & $55(37 \%)$ \\
\hline & High & $17-24$ & $68(45 \%)$ & $42(28 \%)$ & $30(20 \%)$ \\
\hline \multirow{3}{*}{ 4. Emotional discharge } & Low & $<8$ & $45(30 \%)$ & $57(38 \%)$ & $66(44 \%)$ \\
\hline & Average & $9-16$ & $57(38 \%)$ & $54(36 \%)$ & $51(34 \%)$ \\
\hline & High & $17-24$ & $48(32 \%)$ & $39(26 \%)$ & $33(22 \%)$ \\
\hline \multirow{3}{*}{ Total } & Low & $<32$ & $33(22 \%)$ & $67(45 \%)$ & $71(47 \%)$ \\
\hline & Average & $33-64$ & $48(32 \%)$ & $33(22 \%)$ & $37(25 \%)$ \\
\hline & High & $65-96$ & $69(46 \%)$ & $50(33 \%)$ & $42(28 \%)$ \\
\hline
\end{tabular}

The above table presents the Impact of counseling on the Coping responses used by the rural youth at different phases.

- 34 subjects (23\%) who obtained High scores in Approach coping dimension under Coping Response type during pre test, their scores increasedto 39\% (59) during post test-I and to $46 \%$ (69) during post test-II in the same category. Similar finding were observed with subjects who obtained low and average scores during pretest.

- This indicates that handling the situation objectively, finding some personal meaning to the situation \&anticipating the new demands;ability to see the good side of the situation; seeking support from relations, talking to a closed person about the problem and praying for guidance \&strength and using alternate ways / or new ways of confronting the problem was found to be more during post testing. This means that subjects started adopting more of approach coping responses, reflecting the effectiveness of counseling sessions.

- 69 subjects (46\%) who obtained High scores in Avoidance coping dimension under Coping Response type during pre test, their scores decreasedto38\% (57) during post test-I and to $28 \%$ (42) during post test-II in the same category, as the subject's scores moved up to average and low category.

- This indicates that avoiding the situation, denial, day dreaming, and imagining that problems would go away on their own decreased; accepting the situation with all its intensity, realizing that one has no control over the 
problem and believing that outcome would be decided by fate also decreased; getting involved in new activities, making new friends and indulging in more recreational activities increased; yelling or shouting to let off steam, showing the frustration of role capacity on others \&keeping away from people in general too decreased among the subjects during post testing.

This means that the number of subjects who used avoidance coping responses has decreased as they started using more of approach coping in confronting the problem situation, reflecting the effectiveness of counseling sessions.

Table 11

\begin{tabular}{|c|c|c|c|c|c|c|}
\hline \multirow[b]{2}{*}{ Area } & \multicolumn{3}{|c|}{ Total Scores } & \multicolumn{3}{|c|}{ Means } \\
\hline & $\begin{array}{c}\text { Pre } \\
\text { Test(A) }\end{array}$ & $\begin{array}{l}\text { Post Test- } \\
\text { (B) }\end{array}$ & $\begin{array}{l}\text { Post Test- } \\
\text { 2(C) }\end{array}$ & $\begin{array}{l}\text { Pre test } \\
\text { (A) }\end{array}$ & Post Test-1(B) & $\begin{array}{l}\text { Post Test- } \\
\text { 2(C) }\end{array}$ \\
\hline \multicolumn{7}{|c|}{ I. ApproachCoping } \\
\hline Logical Analysis & 1583 & 1708 & 1801 & 10.55 & 11.39 & 12.01 \\
\hline \multicolumn{7}{|c|}{ Table 11: Contd., } \\
\hline Positive appraisal & 1898 & 2012 & 2093 & 12.65 & 13.41 & 13.95 \\
\hline Seek guidance \&support & 2086 & 2297 & 2390 & 13.91 & 15.31 & 15.93 \\
\hline Problem solving & 1537 & 1582 & 1656 & 10.25 & 10.55 & 11.04 \\
\hline Total & 7104 & 7599 & 7940 & 47.36 & 50.66 & 52.93 \\
\hline \multicolumn{7}{|c|}{ II Avoidance Coping } \\
\hline Cognitive avoidance & 2135 & 1983 & 1943 & 14.23 & 13.22 & 12.95 \\
\hline Acceptance & 2022 & 1805 & 1756 & 13.48 & 12.03 & 11.71 \\
\hline Seek alternative rewards & 2142 & 1907 & 1840 & 14.28 & 12.71 & 12.27 \\
\hline Emotional discharge & 2225 & 1980 & 1932 & 14.83 & 13.2 & 12.88 \\
\hline Total & 8524 & 7675 & 7471 & 56.83 & 51.17 & 49.81 \\
\hline
\end{tabular}

Table 12

\begin{tabular}{|l|c|c|c|c|c|}
\hline \multirow{2}{*}{ Area } & \multicolumn{2}{|c|}{ Mean Differences } & \multicolumn{2}{c|}{ T Values } \\
\cline { 2 - 6 } & $\mathbf{A - B}$ & $\mathbf{A - C}$ & $\mathbf{B - C}$ & $\mathbf{A - B}$ & $\mathbf{A - C}$ \\
\hline LA & 0.84 & 1.46 & 0.62 & $9.98^{* *}$ & $1.70^{* *}$ \\
\hline PA & 0.76 & 1.3 & 0.54 & $3.88^{* *}$ & $2.52^{* *}$ \\
\hline GS & 1.4 & 2.02 & 0.62 & $3.17 * *$ & $1.94 * *$ \\
\hline PS & 0.3 & 0.79 & 0.79 & $9.93^{* *}$ & $3.93^{* *}$ \\
\hline Total & $\mathbf{3 . 3}$ & $\mathbf{5 . 5 7}$ & $\mathbf{2 . 2 7}$ & $\mathbf{4 . 4 3}^{* *}$ & $\mathbf{7 . 7 2} * *$ \\
\hline CA & 1.01 & 1.28 & 0.27 & $1.86^{* *}$ & $6.91 * *$ \\
\hline Accept & 1.45 & 1.77 & 0.32 & $5.04^{* *}$ & $9.16^{* *}$ \\
\hline SR & 1.57 & 2.01 & 0.44 & $2.61 * *$ & $5.63 * *$ \\
\hline ED & 1.63 & 1.95 & 0.32 & $7.06^{* *}$ & $7.55^{* *}$ \\
\hline Total & $\mathbf{5 . 6 6}$ & $\mathbf{7 . 0 2}$ & $\mathbf{1 . 3 6}$ & $\mathbf{9 . 7 7} * *$ & $\mathbf{6 . 3 0} * *$ \\
\hline
\end{tabular}

Note: ** At 1\% Level of Significance

The above table presents theoverall Coping response (used by youth) scores of youth total raw scores, means, SD \& ' $\mathrm{T}$ ' values at different phases (pre test and post test I \& II). The table shows the progressive increase in the total scores across pre test to post test $1 \& 2$, along with the increase in the mean differences, which shows the impact of intervention programme. $\mathrm{T}$ values between the two means of pre test and post test I \& II were found to be highly significant, as the calculated values were found to be greater than the tabulated value. 


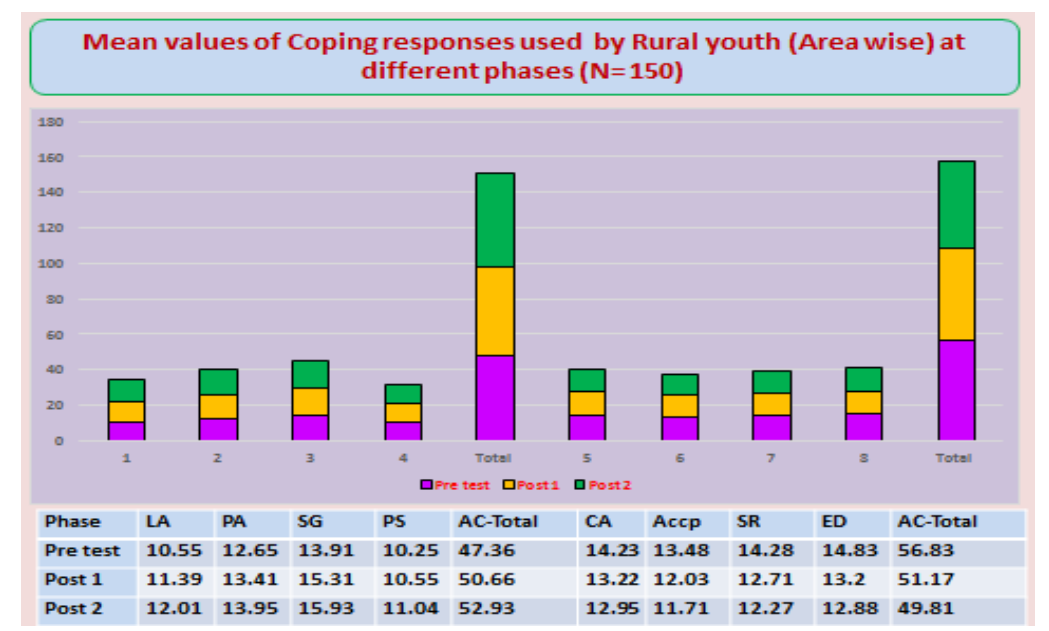

Figure 6: Mean Values of Coping Responses of the Youth (Area wise) N=150

Based on the effectiveness of Counseling, following Conceptual model was developed for promoting Resilience in youth

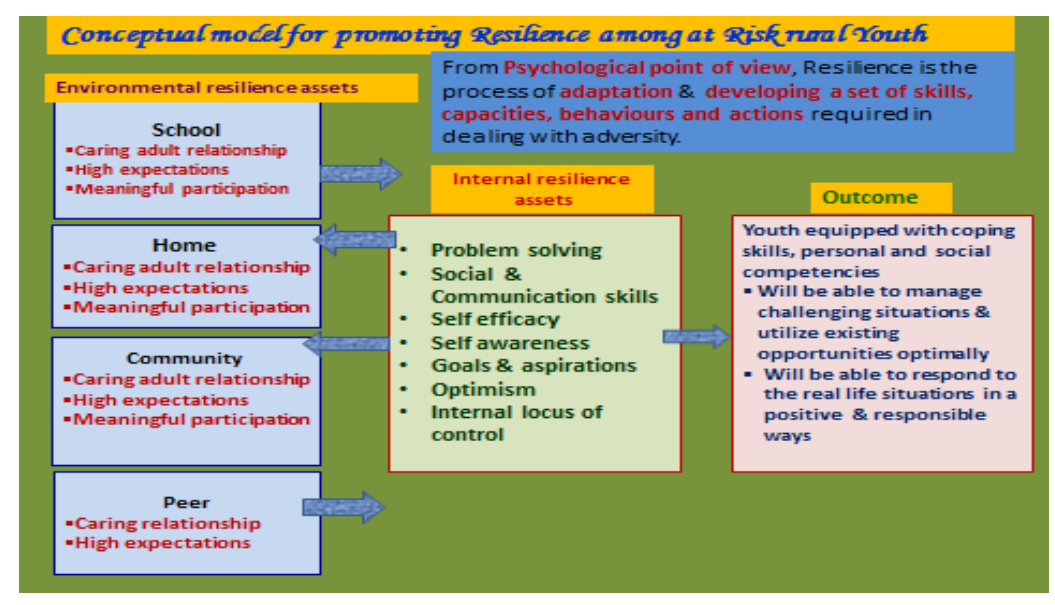

Figure 7

\section{STRATEGIES TO RETAIN YOUTH IN THE MAINSTREAM OF EDUCATION}

Families, Schools, and Communities all Need to Work Together to Create an Environment that Facilitates Healthy Development of Youth / and Adolescents

School Connectedness: Itis the belief by students that adults and peers in the school care about their learning as well as about them as individuals.

\section{Some of the Factors That Can Increase School Connectedness}

\section{Adult Support}

School staff should dedicate their time, interest, attention, and emotional support to students. According to research by Blum (2005), children and adolescents' beliefs about themselves and their abilities are shaped by the extent to which they perceive that the adults in their lives care about them and are involved in their lives. Children and adolescents who feel supported by important adults in their lives are likely to be more engaged in school and learning.In the school setting, students feel supported and cared for when they see school staff dedicating their time, interest, attention, and 
emotional support to them. Students need to feel that adults care about them as individuals as well as about their academic achievement.

\section{Belonging to a Positive Peer Group}

A stable network of peers can improve student perceptions of school. Students' health and educational outcomes are influenced by the characteristics of their peers, such as how socially competent peer group members are or whether the peer group supports pro-social behavior (e.g., engaging in school activities, completing homework assignments, helping others).Being part of a stable peer network protects students from being victimized or bullied.

Strong Interpersonal Skills: Enable students to maintain healthy relationships. Students who report feeling most connected to school also report having the most friends at school and having friends from several different social groups that are integrated by race and gender. Conversely, those students who report feeling less connected to school have more friends from outside school than inside or are socially isolated, reporting few friends either inside or outside of school.

\section{Commitment to Education}

Believing that school is important to their future, and perceiving that the adults in school are invested in their education, can get students engaged in their own learning and involved in school activities. It is important that both students and adults are committed to learning and are involved in school activities. Students' dedication to their own education is associated with the degree to which they perceive that their peers and important adults in their lives 1) believe school is important and 2) act on those beliefs.

\section{School Environment}

The physical environment and psychosocial climate can set the stage for positive student perceptions of school.Connectedness is enhanced by a healthy and safe school environment and a supportive psychosocial climate. A clean and pleasant physical environment (e.g., one free from graffiti) raises expectations for safety and sets the stage for positive, respectful relationships (Ryan, 2001).

Following IEC material: Has been developed in vernacular language for thekey persons in the village for the continuation of the programme

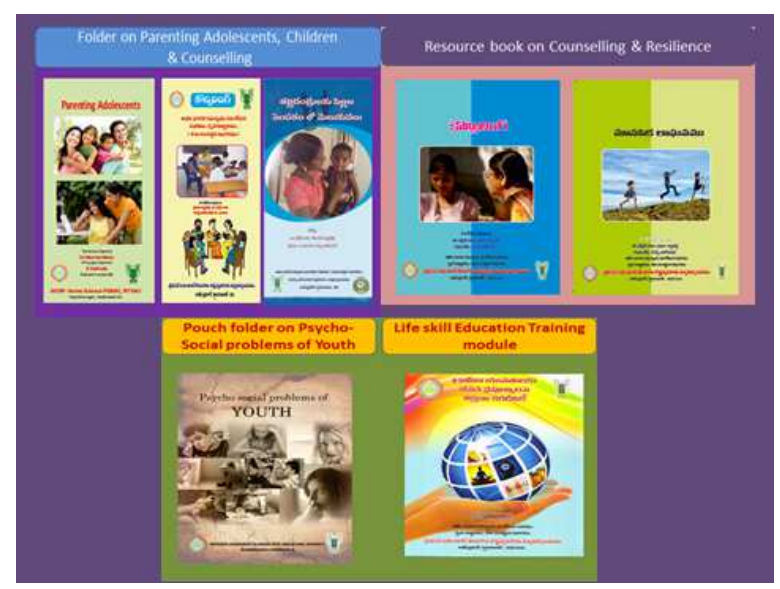

Figure 8 


\section{CONCLUSIONS}

Adolescent development matters a serious concern not only for parents but also to school people and other adult who are interested in the present welfare of youth as well as in the future progress of our society. Before we delve into the problems of adolescents, it is necessary to understand what is happening to the teen physically, emotionally, cognitively and socially.

Life for many adolescent is a painful tug of war filled with mixed messages and conflicting demands from parents, teachers, friends, family and themselves. If the problems of adolescents are not identified and helped during their school days would continue to have difficulties dealing with society and their problems may become progressively more serious in later life.

Families, schools, and communities all need to work together to create an environment that facilitates healthy development of children and adolescents. Research has shown that students who feel more connected to school are more likely to have positive health and education outcomes.

\section{REFERENCES}

1. Betancourt, T.S; Speelman, L; Onyango, G; Bolton, P. (2009). Psychosocial problems of war-affected youth in Northern Uganda: A qualitative study. Transcult Psychiatry;46:238-56

2. Blum, R. (2005). School Connectedness: Improving the Lives of Students. Baltimore: Johns Hopkins Bloomberg School of Public Health.

3. Burnard, P. 1995. Counselling Skills for Health Professionals. Second Edition. Chapman \& Hall, London.

4. Gilborn, L;Apicella, L; Brakarsh,J;Dube, L; Jemison, K; Kluckow, M.(2006). Orphans and vulnerable youth in Bulawayo, Zimbabwe: An exploratory study of psychosocial well-being and psychosocial support.

5. Haugaard, J. J. (2001). Problematic behaviours during adolescence. New York: Mc Graw-Hill.

6. Hurlock, B. E. (1981). Developmental psychology-A life span approach. New York: Mc Graw Hill Book Company.

7. Ryan, A.M, Patrick, H. (2001). The classroom social environment and changes in adolescents' motivation and engagement during middle school. American Educational Research Journal;38(2):437-460. 
